Article

\title{
Neutral Spectators from a Distance? American Jews and the Outbreak of the First World War
}

\author{
Sarah Panter \\ Leibniz Institute of European History (IEG), Department of History, Alte Universitätsstraße 19, 55116 Mainz, \\ Germany; panter@ieg-mainz.de
}

Received: 5 June 2018; Accepted: 16 July 2018; Published: 18 July 2018

\begin{abstract}
As the First World War broke out in 1914, American Jews seemed far away from the upheaval in Europe. Yet their role as neutral spectators from the distance was questioned right from the outset because of their diverse transcultural entanglements with Europe. Seen from a specific Jewish perspective, the war bore the potential of becoming a fratricidal war. In particular at the Eastern front it was a likely scenario that Jewish soldiers fighting on either side would have to face each other in battle. For Jews, depending on how one defined Jewishness, could be regarded as citizens of a particular nation-state or multi-ethnic empire, as members of a transnational religious community or as members of an ethnic-national diaspora community. Against this background, this article attempts to shed fresh light on the still under-researched topic of American Jewish responses to the outbreak of the First World War. Although American Jewry in 1914 was made up of Jews with different socio-cultural backgrounds, they were often regarded as being pro-German. The war's impact and the pressures of conformity associated with these contested loyalties for American Jews did therefore not just unfold in and after 1917, but, as this article emphasizes, already in 1914.
\end{abstract}

Keywords: First World War; Jewish; American Jews; minorities in wartime; neutrality; Europe; war experience; loyalties

\section{Introduction}

Only a few months after the outbreak of war in Europe, Bernhard Dernburg, a representative of the German government in the US, was invited as an honorary guest to a banquet of the Young Men's Hebrew Association in New York. Before the summer of 1914 one could have expected that many Jews might have protested this invitation because Dernburg's father had converted to Protestantism before the birth of his children. Thus, it seemed obvious that Dernburg did not really qualify as the best example for the Jewish youth of America. In December 1914, however, this objection was only of secondary importance for Jews in the United States. Critical voices against Dernburg's invitation were primarily linked to another fear: that his presence at the banquet could be regarded by other ethnic minorities—or even by American society as a whole-as a breach of neutrality on the part of American Jews (Marshall to Schiff, 30 December 1914, AJA ${ }^{1}$ ).

For some American Jews such an identification with the German-speaking parts of the Central Powers that was underlying these fears was strong; for others, and in particular for Yiddish-speaking immigrants with family roots or birth places in Eastern Europe, support for the Central Powers stemmed from a different motivation: their contempt for Czarist Russia because of the empire's

1 On Louis Marshall's attitude during the war, see (Silver 2017, pp. 303-25). 
dark Jewish past and present (Rappaport [1951] 2005; Manor 2009; Estraikh 2017, pp. 279-302²). Nonetheless, under the circumstances of American neutrality, allegations that Jews in the US were not only culturally, but also politically leaning pro-German could become a source of individual as well as collective conflict. And the longer the war lasted, with its rise in anti-German feeling in US public opinion, in particular after the sinking of the Lusitania in May 1915, the more threatening this overlap of anti-German and anti-Jewish sentiment turned out to be (Panter 2014, pp. 327-39).

American Jews were not the only group within the United States affected by their multiple loyalties: the war, for example, equally challenged Socialists and Catholics, who belonged to different ethnic minorities, to defend their internationalism or transnationalism and at the same time to demonstrate their patriotism as American citizens (Houlihan 2015, pp. 1-19). The same applies to ethnic minorities during the war around the globe in general (Ewence and Grady 2017; Leonhard 2018) and in the US in particular (Sterba 2003; Capozzola 2008). African Americans-to illustrate such a comparative relevance of the war to ethnic minorities-viewed the war through a "pan-African" mirror, comparing, for example, German atrocities in Belgium in 1914 with "racial violence in the Congo and the United States" (Keene 2014, p. 274). Irish Americans, in contrast, initially adopted a pro-German stance in the cause of Irish nationalism and autonomy, emphasizing the un-Americanism of England (French 2012, pp. 239-45).

German Americans certainly experienced the most violent vigilantism and attacks connected to such anxieties of divided loyalties during the war. Furthermore, as a result they saw German culture in the US shattered (Wüstenbecker 2014). Yet, compared to German Americans, who were torn between sympathy toward their (old) Vaterland and (new) fatherland, American Jews stood even more so in-between, because they were connected to multiple fatherlands. The Jewish situation appeared therefore far more complex, as 'Jewishness' could be defined either in religious, ethnic or national terms and the struggle about different notions of Jewish identity and belonging found multiple answers. Across the spectrum of Jewish opinion, different leadership groups contested the right of others to speak in the name of the Jews as a whole. This challenge, in turn, was often connected to different local experiences and links to transnational aspects of Jewish (non-)involvement during America's phase of neutrality and beyond. In this sense, American Jewry resembled the diversity of American society; or as Jennifer Keene put it: "America in 1914 was a divided nation that found it impossible to speak with one voice on any matter" (Keene 2014, p. 266).

This article examines how the outbreak of the First World War in (and beyond) Europe created a complex challenge for American Jews that was shaped by the dynamics of three interrelated issues: the relation between notions of Jewish belonging in the United States and their perceptions in Europe, the perceptions of the war within the American Jewish community, and the locally-based dynamics of civic patriotism. In so doing, the following analysis not only integrates the specific situation of Jews within the general context of early American neutrality, but also incorporates a transatlantic perspective on 'neutral' Jewish responses at the outbreak of the war. It furthermore argues that in this phase of early neutrality the US itself constituted a transnational space in which the multiplicity of Jewish opinion fomented an unprecedentedly intense political debate. ${ }^{3}$ Most of the attention of previous scholars has been focused on the nature of that debate following America's entry into the war in April 1917. This essay, in contrast, focuses mainly on the period between August 1914 and the early part of 1915. Such a perspective on the early phase of American neutrality demonstrates not only the powerful impact of the war on American Jewry before 1917, but also opens up further avenues of comparison with Jewish communities in countries already at war since the summer of 1914. ${ }^{4}$

2 Important anti-Jewish watersheds in Russia were not only the empire's history of pogroms and anti-Jewish quotas in the sectors of higher education but also the restrictions on Jewish residency outside the Pale of Settlement that lasted until 1917. See (Lambroza and Klier 1992).

3 On the ongoing debate about how to write a transnational history of American Jewry, see (Kahn and Mendelsohn 2014).

4 On the general lack of research on this 'forgotten war' in American historiography, see (Keene 2016, pp. 439-68). 


\section{Competing Visions of War: American Jewish Agency during the First Months of Neutrality}

From August 1914, it took more than two and a half years until the American nation became directly involved in the war. At first glance, the war in Europe seemed to be of only secondary importance for the every-day routine of American life. As John Higham pointed out in his classic book Strangers in the Land, "Europe seemed a long way off" (Higham [1955] 2007, p. 194). Correspondingly, in the summer of 1914 a tendency toward indifference was observed not only in many parts of the general population, but also within intellectual circles. Nonetheless, the situation was more complex, for American society was already challenged by the question of how to handle the huge immigration waves that had brought many future citizens with a predominantly Eastern European background to American shores (see e.g., (Diner 2004, pp. 71-111; Lederhendler 2016, pp. 56-131; Zahra 2016)). As a community embracing many immigrants, Jews, like Germans, Italians, Poles or the Irish, felt the outbreak of the war thus right from the start in August 1914 (Kennedy 1993, pp. 213-27; Traxel 2006, p. 135; Gerstle 2001, pp. 44-80; Sterba 2003).

The specific challenge facing American Jews is reflected, for example, in the correspondence between two influential members of New York's Jewish community: Louis Marshall, a prominent attorney, an advocate of free immigration, and head of the American Jewish Committee, and Jacob H. Schiff, the well-known financier and philanthropist, who had been born in Frankfurt in $1847^{5}$. Their standing both in the American Jewish and the German American community as well as their links to non-Jewish policy makers and entrepreneurs afforded them a particularly well-informed but also highly personal perspective on the war. Their example is thus highly instructive, with regard to the range of opinion among American Jews with family roots in Germany. ${ }^{6}$ Marshall wrote to Schiff to clarify his position. Despite his family's German origins, Marshall felt he could not share Schiff's assumption about his "natural" sympathies-that is, an unquestioned pro-German stance. Not only were Marshall's parents' recollections of Germany rather negative, but also, speaking broadly of American Jewish affairs, it was of paramount importance to "maintain absolute neutrality" (Marshall to Schiff, 30 December 1914, p. 1, AJA7).

There were approximately 3 million Jews living in the United States on the eve of the war (Diner 2004, p. 88; American Jewish Year Book 1917-1918b, pp. 409-10). Most of them were, however, more recent immigrants from Eastern Europe. Nevertheless, American Jewish communal and philanthropic hierarchies up to that point in most localities were still dominated by the so-called 'German' Jews. ${ }^{8}$ In forming a new relief agency in November 1914, the American Jewish Joint Distribution Committee (JDC), Marshall and his fellow members of the 'German' Jewish elite had to find common ground with popular relief organizations that already existed in the larger Jewish community. Further changes lay in store, as indicated in the internal negotiations over the formation of a proposed American Jewish Congress, which began to take shape in early 1915 (Goren 1999, pp. 110-44; Loeffler 2015, pp. 367-98). In 1914, many of these 'new' immigrants-but also many of the 'older' immigrants whose places of origin were, roughly defined, somewhere in the German-speaking lands-still maintained close ties to their relatives or business partners in Europe. Moreover, their majority resided in places that were now heavily affected by the war, either as soldiers or as civilians (Liulevicius 2000; Aschheim 1982). The Eastern front, for example, stretched across an area marked by densely populated Jewish settlements; there the outbreak of the war soon turned into a humanitarian catastrophe. Furthermore, the aggravation of the Jewish situation in Eastern Europe

5 Louis Marshall was born in Syracuse, N.Y. in 1856. He died in 1929 in Zurich, Switzerland. He was the main American Jewish delegate to the Paris Peace Conference in 1919. Jacob Schiff arrived in the United States in 1865 and died in New York in 1920 (Marcus and Daniels 1994, pp. 422, 562).

6 For a good overview of the negative impact of the war on German Americans, see (Luebke 1974; Proctor 2014, pp. 213-34).

7 On the experiences of Marshall's parents in Germany, see (Marshall to Schiff, 30 October 1914, p. 2, AJA).

8 The terms 'Russian' Jews and 'German' Jews, when used uncritically, often ignore the diversity among and between Jewish immigrant communities. (Diner 2004, pp. 78-83; Brinkmann 2014, pp. 144-64). 
and Palestine, where Jews lived under Czarist and Ottoman rule, respectively, would soon arouse an intensified debate about Jewish rights abroad (Frommer 1978; Lederhendler 1997, pp. 104-39).

From a global Jewish perspective, insofar as Jewish communities were rooted in the countries' political environments, the war threatened from the outset to become a fratricidal war, pitting Jews against other Jews. Given that during the war a total of about 1,250,000 Jews (Abramson 2008, p. xviii) fought in the belligerent armies, this was no mere abstraction. German and Austro-Hungarian Jewish soldiers, for example, faced Russian army units that included Jewish combatants. Similarly, British and French Jewish soldiers fought German Jews on the Western front. Although probably apocryphal, a popular tale circulated about two Jewish soldiers serving in opposing armies meeting in battle and unwittingly fire upon one another. The one, hearing his supposed enemy cry out the traditional words of a dying Jew, "Shema yisroel!," becomes grief-stricken and loses his mind (Ansky [1925] 2002, p. $23^{9}$ ). While the story may have been a kind of urban legend, it illustrates the fear of a fratricidal war (Penslar 2013, pp. 121-65; Saperstein 2010, pp. 121-23). Moreover, the multiple loyalties of Jews could put them in a very vulnerable position at home: In times of crisis and upheaval, when an emphasis was put on clear-cut national loyalties, different identity groups living in warring nations were categorized accordingly into 'friends' and 'enemies'. Jews, whom others often associated with a cosmopolitan-internationalist orientation, were prominent targets onto which collective fears could be projected (Gidley 2003, p. 194; Lohr 2003; Stibbe 2014, pp. 479-99).

Not surprisingly, then, in this situation the multi-ethnic composition of the American nation seemed particularly susceptible to becoming a symbolic battlefield for a transnational proxy war. President Woodrow Wilson had this imminent danger clearly in mind when he issued his Message on Neutrality on August 19: "The United States must be neutral in fact as well as in name during these days that are to try men's souls. We must be impartial in thought as well as in action, must put a curb upon our sentiments as well as upon every transaction that might be construed as a preference of one party to the struggle before another" (Wilson 1914). Wilson's appeal for unity implied that all particularistic, non-American loyalties had to be put on hold in the public sphere. Despite not being directly involved in the war and despite being subject to quite different political circumstances in times of neutrality, American Jewry soon had to face a challenge similar to that facing its European counterparts: to negotiate the relationship between ethnic and civic loyalties, or, put differently, between particularistic and universalistic notions of Jewish belonging.

After the outbreak of the war, many Jewish communities in Europe had justified the war either as a defensive war at home (Germany, Austria, Britain and France) and/or as a war of liberation for Russian Jews, a claim that was particularly pertinent among Jews in Germany and Austria (Panter 2014, pp. 46-65). The Yiddish-language immigrant press in New York, which hoped that the war would finally crush the Czarist regime and thus free their families and friends over there from the yoke of anti-Jewish policies in Russia, also shared the latter interpretation. The American Jewish establishment with family roots in Central Europe also pleaded for a liberation of Jews from the Czarist rule. Yet they preferred to put forth another strand of interpretation: a distinctive Jewish love of peace, accompanied by the moral condemnation of all kinds of war as illegitimate means of political struggle. This interpretation corresponded also with a strong emphasis on their vision of a kind of American (Jewish) exceptionalism, and was therefore linked, as one article in Baltimore's Jewish Comment put it, to the self-perception of the United States as "hope of the world" and "home of freedom" (Jewish Comment 1914, p. 258).

In general, these reflections revolved around the opposites of 'war' and 'peace' as well as 'barbarism' and 'civilization'. The English-language Jewish periodicals at first condemned the war with a notable unanimity. In doing so, they referred to the negative effects of the war and in particular its threat to universalistic and humanitarian ideals of modern (Western) civilization. One of the

9 S. Ansky was the pseudonym of Russian and Yiddish writer Shloyme Zaynvl Rapoport (Safran 2010). 
leading American Jewish journals, the American Hebrew, for example, wrote on 14 August that the "war spirit" was an "imposition upon civilization" and had to be fought by a "spirit of humanity" (American Hebrew 1914a, p. 413).

Publishing an article in Pittsburgh's Jewish Criterion, Stephen S. Wise-American rabbi, Zionist and well-known pacifist-evoked the negative character of the war at the end of October 1914 even more vividly. He pointed out that when it comes to war there are "no victories, only defeats". Only if humanity were able to recognize the moral dimension of the war, putting aside all material interests and ideals of masculinity already in times of peace, could future wars be prevented: "If war is to end, it is the war within our souls that must go. Physical preparedness alone does not make war. It is moral preparedness for war which makes armaments possible and wars inevitable" (Jewish Criterion 1914b, p. 8). In addition, Wise's statement also deserves attention because it addresses the problematic situation of women in war. In his opinion, wives and mothers were-because of losing their husbands and sons-one of the war's main victims, even though they lacked equal citizenship rights, such as the right to vote. After the outbreak of the war in Europe, Wise had been one of the most outspoken proponents of pacifism (Szajkowski 1972, p. 78; Kennedy 1980, p. 33). As a very visible public figure he therefore helped to shape the image that a distinctive Jewish love of peace was identical with America's civilizing mission in the world. During the first months of the war, public discourse among many American Jews thus depicted patriotism, pacifism and neutrality as synonymous terms (see e.g., (American Israelite 1914, p. 1)). ${ }^{10}$

Many European Jews by contrast — even if they might have shared this position in private-were no longer able to voice such an interpretation openly, because their society's wartime patriotism had led most of them to take on a strict stance in legitimizing their nation's engagement in the war.

Not only American Jews but also other groups, such as German Americans, pacifists and socialists, put much effort in keeping the United States out of war. As the United States transformed itself from a neutral to a belligerent power between 1914 and 1917, Wise, like so many others, who usually never bowed to the pressures of conformity, would nevertheless fully support US involvement in the war. Judah Magnes, by contrast, who was both a leading Jewish activist in New York and a leading pacifist, chose a different path. Indeed, the war triggered a gradual radicalization of Magnes's pacifism and non-conformism. This made him subject to investigations into anti-American activities by the Justice Department as well as of inner-Jewish criticism. ${ }^{11}$

Another illustrative example for such dissenting behavior within American Jewry is the case of Moravian-born Gotthard Deutsch. His pacifist and pro-German sympathies became a pressing, if not partly embarrassing, issue for American Jews on a local and a national level in 1917/18, when he opted not to make a clear statement about his sympathies for an American or German victory. A professor at Hebrew Union College in Cincinnati since 1891, and heavily involved with Jewish and German affairs, his cultural legacies from Europe partly shaped his attitude. Hence, his wartime "ordeals" are a good case in point for how contested Jewish identities had become, especially in an atmosphere of heightened hysteria on the American home front. As G. A. Dobbert argued, back in 1968, Deutsch's transnational biography was insofar 'untypical', as he did not fit the usually-applied categories of 'German' and 'Russian' Jews: "[G]eographically [he] was part of the 'new' east European Jewish immigration; culturally, however, he belonged firmly in the older German-Jewish immigrant wave which had preceded the former by about half a century" (Dobbert 1968, p. 132).

10 On Woodrow Wilson's policy and its international impact, see (Manela 2009; Tooze 2014).

11 In the preface of the collected volume of Magnes's wartime speeches published in 1923, he also blamed Woodrow Wilson for attacking non-conformists during the war and, hence, "to crush, all discussion that did not blindly and ignorantly accept his [i.e., Wilson's] idealizations" (Magnes 1923, p. 8). In this context, and despite his public statements before 1917, in which he had urged American Jewry to adopt a neutralist position, he was now accused of being 'pro-German'. By that time, pacifism and socialism had turned into synonyms for un-American, i.e., disloyal, behavior in the mind of the American (Jewish) public (Kotzin 2010, pp. 144-55). 


\section{Entangled Perceptions: American Jewish Sympathies and Legacies from the Past}

As the war in Europe and the Middle East dragged on and had a larger impact on the United States in general, the practical consequences of divided American Jewish sympathies toward the belligerents attained greater significance. In this context, markers of difference between native and foreign Jews, like citizenship status, religious or cultural-linguistic affiliations, became ever more complex. These dynamics, though taking on specific and more concrete forms, were rooted, however, in stereotypes that predated the war.

Shortly after the outbreak of the war in the summer of 1914, the Yiddish-language periodicals in New York had outspokenly expressed their sympathies with Germany's fight against Russia. Many Jewish immigrants from Eastern Europe indeed hoped that a German victory would lead to a liberation of Russian Jews from Czarist oppression (Rappaport [1951] 2005; Manor 2009, pp. 72, 81; Estraikh 2017, pp. 279-302). Journalistic rhetoric seems to have overlapped here with emotionally charged sympathies, rooted in personal memories of difficult circumstances. Inevitably, information arrived from Eastern Europe with a certain time delay. Furthermore, very often American Jews were confronted with conflicting reports about the Jewish situation in Europe, so that it was not always clear which sources were reliable. At the beginning of 1915, for example, Arthur Levy, a Jewish chaplain in the German army, countered reports in the American Hebrew that had downplayed Russian atrocities against Jews in Poland. In his open letter addressed to the editors, Levy wrote:

I have had news sent to me on the field of battle, where I am occupied as Rabbi for the Jewish soldiers of the German army, that in your respected and widely-read paper, a notice has appeared which attempts to minimize the well-known deeds of the Russians in Radom, about which full information was given at the time in the Berliner Tageblatt, and an attempt made to transfer the guilt elsewhere. As I was the original author of that account, I feel responsible for its authenticity and take the liberty therefore to assure you, most solemnly and earnestly, that it is literally true (American Hebrew 1915, p. 371²).

Whereas reports about Russian atrocities against Jews were a pressing issue for American Jews, the general public humanitarian discourse in the US had focused initially much more on German atrocities in Belgium. Mainly on a symbolic level, this put Jewish interests partly in conflict with American relief interests in Europe. One commentator, Joseph Snitzer, for example, urged American Jews to take particular Jewish interests to heart, as a higher priority, when comparing the situation of Jewish and Belgian victims and civilians:

We care not how many Belgian graves there are in Belgium —-there are more JEWISH graves in Poland. [ ... ] Our own house is burning, [ ... ] our ancestral homes to which we are tied with thousands of endearing threads are being razed to the ground [ ... ] —and we, the happy dwellers of this grand land, have not made the slightest move to liberate them. [ ... ] Jews of America, what have you done for your own flesh and blood? (Jewish Criterion 1915, p. 5).

Around the same time, Henry Morgenthau Sr., American ambassador in Constantinople, and himself born in Mannheim, Germany, had warned the public about the plight of Palestinian Jews under Ottoman rule. More importantly, he was appealing for help regarding the "Armenian massacre[s]" (Morgenthau 1919, p. 301) and officially reported all atrocities he had witnessed or had knowledge of through conversations with American consuls and missionaries. Furthermore, through his friend Adolph Ochs, editor of the New York Times, he was assured that "the massacres continued to receive prominent coverage-145 articles in 1915 alone" (Oren 2007, p. 336). Morgenthau and his family would leave Constantinople in early 1916. Via Berlin and Copenhagen, they would reach New York

12 On the same day, this open letter appeared in the widely-read newspaper Jüdische Rundschau (Jewish Review), published in Berlin by German Zionists. (Jüdische Rundschau 1915, pp. 45-46). 
in February, where he started to put all his resources into the re-election of Woodrow Wilson (ibid., pp. 384-407). On the one hand, his "failure to stop the destruction of the Armenians" influenced his decision to leave Constantinople because it had turned "Turkey [ ... ] into a place of horror" (ibid., p. 385). On the other, he also was disappointed about the slow response of his own government fearing too much public attention on the Armenian genocide, which ran counter to official American interests in the international conflict (Greiner 1995, p. 27). Morgenthau's dilemma thus contrasted somewhat with the hesitant politics of his government, but it was also not crafted from the ethnocentric politics of many Jewish immigrants, for whom Jewish troubles on the Eastern front were what mattered most. Thus, even before 1917, one could not point to one united or unanimous American Jewish voice.

Immediately after the outbreak of the war, the public debates among American Jews about the international political situation were characterized mainly by strategic considerations vis-à-vis America's elites: avoiding the dilemma of taking sides, in particular by distinguishing between the 'politics' of the belligerents and their 'cultures'. This differentiation between German 'politics' and 'culture' was not specific to American Jewish discourse. On various occasions, for example, it had found expression as well among Jews in Britain, who had to fight the allegation, as Leopold Greenberg, the editor of the Jewish Chronicle, stated to the non-Jewish public, "that every Jew is necessarily a German" (Times (London) 1914, p. $3^{13}$ ). By comparison, however, American Jews referred to this argument quite frequently during the first months of the war to accentuate a distinctive message: that it was necessary to avoid a condemnation of all ideals historically associated with Germany. At the same time, there was another strategic motive behind this argument, for it was also thought to be helpful in legitimizing existing cultural ties, family bonds and (at least in some cases) business relations with Germany. Furthermore, this trend lasted well into early 1917 (see e.g., (Wise to Gottheil, 2 February 1917, AJA)). Yet beyond the public sphere, many American Jews with roots in the German-speaking lands were indeed deeply split when the question was raised of whether one should adhere to a strict stance of neutrality. Thus, the necessities of political reason could clearly clash with the emotional implications of the war. Even after 10 months into the war, Jacob Schiff, for instance, openly admitted the difficulty of separating his personal feelings from public considerations of neutrality. In a letter sent to Anglo Jewish diplomat Lucien Wolf in London he stated accordingly:

I am perfectly frank to say, my sympathies in this lamentable and terrible conflict are on the side of Germany, because I have not only been born and educated there, but because also my forebears have lived in Germany for many centuries, and I would just as little think of turning against it in this hour of its struggle and peril, as I would turn against my own parents were their existence endangered (Schiff to Wolf, 14 June 1915, CZA ${ }^{14}$ ).

Although this statement to Lucien Wolf, one of the main (anti-Zionist) actors in the field of Anglo Jewry's international relations before and during the war, shows Schiff's deep attachment to the country of his family's origin, his correspondences with Jews in Germany, in turn, reveal another important aspect: namely, that Schiff's narrative depended very much on the context and the possible audience of his letters. After the German press had attacked Schiff, for instance, in February 1915—paradoxically enough - because of his neutral position, he wrote an outraged letter to leading members of German Jewry's liberal establishment, Paul Nathan in Berlin, as well as Max Warburg in Hamburg. In it, he complained that

the dear Germans [ ... ] have completely forgotten that I was already an American citizen at a time, when the German Empire had not existed yet. [ ... ] Hence, no one can expect

13 On similar accounts in the American Jewish press regarding the complex situation of British Jewry in 1914, see (American Hebrew 1914c, p. 430; American Israelite 1914, p. 3).

14 On Wolf's role during the war, see (Levene 1992). 
from me now that I share exactly the same opinion as the good old-fashioned German [der Ur-Deutsche] (Schiff to Nathan and Warburg, 16 February 1915, AJA ${ }^{15}$ ).

Sympathies for Germany and the need at the same time to distance oneself publicly from the current state of Germany were thus closely intertwined and sometimes difficult for someone like Schiff. The pressure of conformity within the public sphere at that time was therefore tied to different structural circumstances than the ones facing European Jews in a state of total war. Some of the more openly pro-German voices within American Jewry, for example, pointed to-and thus indirectly justified - the precarious situation of Germany, which, as the argument ran, had to defend herself against "Slavic" (i.e., Russian) ambitions for expansion in Eastern Europe (American Hebrew 1914b, p. 411). This image therefore paralleled features of the highly charged discourse about the 'East' in Germany, deeply rooted in German history (Ingrao and Szabo 2007).

The complexity of American Jewish identities may be seen in Schiff's ambivalent correspondence with German and British Jews and points also to a more general trend: the challenge of contested loyalties in times of war. For starting in the beginning of 1915, the pressure from within American society—and especially from those groups leaning toward the Allied Powers-had polarized American Jewry's discourse on neutrality further. This, in turn, led to mutual accusations among American Jews of having violated 'neutrality'. The term itself had by then clearly become rather vague and symbolized not only general fears of disloyalty, but also pointed specifically to the ongoing debates about 'Americanization' and so-called 'hyphenated' Americans (see e.g., (Kallen [1915] 1996, pp. 67-92; Friedlaender [1915] 1919, pp. 331-52)). In some instances, such struggles took place in the public sphere. One reader of Baltimore's Jewish Criterion, for example, had cancelled his subscription because he accused the newspaper's editor of anti-German sentiment. The editorial staff rejected this allegation, in turn, by referring to structural factors: British dominance of the press and all information coming from Europe due to the cutting of Germany's submarine telegraph cable (Jewish Criterion 1914a, p. $\left.3^{16}\right)$. In sum, there was not one but multiple Jewish voices that have to be factored in when looking at American Jewish responses following the outbreak of the war.

\section{Pressuring Beyond Neutrality: The Transnational Contest for Jewish Sympathies in America}

As the war went on and seemed unlikely to end quickly, news about the wartime distress of Jews abroad reached American shores. This, in turn, led not only to a greater awareness about the dramatic humanitarian situation of Jews in Eastern Europe or the Middle East, but also played an important role in catalyzing a power struggle over Jewish humanitarian aid on a transnational scale. Hence, American Jewish cleavages at home were clearly intertwined with the dynamics of the international (Jewish) situation. This resulted, for example, in an intensive discussion about how the distress of Jews in Eastern Europe could be relieved and what position American Jewry should take in international Jewish affairs, and especially vis-à-vis the German Jews organized in the Hilfsverein der deutschen Juden (Aid Association of German Jews), which was active in humanitarian aid to Jews on the Eastern front. American Jewish relief efforts that merged together in the founding of the JDC in 1914/15 not only served to counter the German Jewish Hilfsverein's dominance in the field, but also had the symbolic potential of bridging ethnic and ideological rifts within American Jewry, bringing recent immigrants from Eastern Europe and descendants of Central European Jews together in order to aid their Jewish brethren in need (Tessaris 2010, pp. 127-44; Granick 2014, pp. 55-68).

15 Emphasis in the original. I have translated into English all quotations from German sources. Especially during the first two years of the war, Schiff had exchanged many insightful letters with Max Warburg in Hamburg. See (Box 440, Folders 7-9, MS-456, AJA). Max was the brother of the Jewish activist Felix Moritz Warburg, who had lived in New York since 1894 and was married to Schiff's American-born daughter, Frieda. Here the 'war of brothers' took on a very literal meaning.

16 For the malfunctioning of the German communication system and the British dominance of news coverage, see (Daniel 2008, pp. 48-56; Nickles 2003; Sanders and Taylor 1982, p. 171). 
The plight of Eastern European Jews had become acute already in the autumn of 1914, triggering relief efforts and donation campaigns. The already-mentioned JDC was founded on November 24 and consisted initially of two, and as of 1915, three committees that represented different factions within American Jewry: The Central Relief Committee under the leadership of M. Z. Margolies that represented Orthodox Jews, the American Jewish Relief Committee that consisted partly of members from the American Jewish Committee (Felix Warburg, Julian Mack, Louis Brandeis, Louis Marshall, Judah L. Magnes), and, finally, since November 1915, the People's Relief Committee under the leadership of Meyer London and Scholom Asch that represented Socialists, in particular from New York (American Jewish Year Book 1917-1918a, pp. 194-227; American Jewish Year Book 1916-1917, pp. 307-10; Engelman 2016; Handlin 1964, pp. 19-32).

Each committee undertook local grass roots campaigns to collect donations all around the country. The JDC - as the umbrella organization - in turn was responsible for the transfer and circulation of American relief money to Jews in Eastern Europe. For the money to reach its recipients it had to rely on mediating institutions, such as the Jüdisches Hilfskomitee für Polen und Litauen (Jewish Aid Committee for Poland and Lithuania) in the German occupation zone and the Israelitische Allianz zu Wien (Alliance Israélite of Vienna) in the Austrian occupation zone. In terms of distributing the money on the ground in Europe, American Jews could thus only act indirectly. This geographical distance restricted the opportunities of American Jews to have a clear oversight about the actual distribution of their relief money and hence to directly influence the course of international Jewish relief action. Against this background, different notions of Jewish transnational relief work and Jewish solidarity could clearly clash, at times pitting European and American Jewish opinion against each other. Furthermore, there were conflicting ideological implications involved, depending on the position adopted by various leadership groups. The dominance of non- or anti-Zionist German Jews in this endeavor meant that the ethnic-national self-identification of Jews in Eastern Europe was mainly ignored in 1914/15. ${ }^{17}$

Another field of American Jewish relief effort was the situation of Jews in Palestine. As already mentioned, at the end of August 1914, Henry Morgenthau had cabled from Constantinople to Louis Marshall and Jacob Schiff that it was necessary to immediately raise $\$ 50,000$ to aid the Jews in need owing to pressure by the Ottoman authorities against non-Ottoman nationals, including most of the Jews then living in Palestine. At that time in Ottoman-ruled Palestine there lived appr. 85,000 Jews. ${ }^{18}$ The money would finally arrive in Jaffa on October 6 on board the USS North Carolina and be transmitted to Jews there via German-born Arthur Ruppin, head of the Zionist Organization office in Palestine. During the war, the JDC would transfer about $\$ 35$ million in aid money for the relief of Jews to Palestine (Carenen 2017, p. 2). Yet, the relief efforts for Jews in Eastern Europe, with its 6 million Jews, always dominated the relief discourse within American Jewry throughout the war-even though many American Zionists were keen to strengthen its Jewish nationalist orientation, e.g., by using mainly Zionist channels to distribute the money (Carenen 2017, p. 444).

An American Jewish proponent of a strict anti-German stance was Richard Gottheil, who had been born in Manchester in 1862 before his family had immigrated to New York in 1873. Gottheil's father Gustav, in his later years a Reform rabbi at temple Emanu-el in New York, was actually born in Pinne (today: Pniewy/Poland), located in the Prussian province of Poznań. In 1914, his son Richard, despite his transnational academic biography (including stays in Berlin, Leipzig and Tübingen during the 1880s), was now countering perceptions in allied circles of the "apparent German leanings of the Jewish masses and leaders", as he wrote in a letter to philosopher and Zionist Horace Kallen (Gottheil to Kallen, 19 October 1914, AJA). Gottheil was a leading member of the Federation of American

17 On the German relief committee, see (Hilfsverein der deutschen Juden 1917, pp. 9, 11). The Hilfsverein communicated queries for support from the German occupation zone to the American Jewish Relief Committee, which, in turn, informed their relatives in the United States.

18 Caitlin Carenen quotes a source that mentions 150,000 Jews living in Palestine in 1914 (Carenen 2017, p. 445). The American Jewish Year Book lists, however, only 85,000 Jews living in Palestine in 1916 (American Jewish Year Book 1918-1919, p. 340). 
Zionists since its founding in 1897 in New York. During the war, he was also a member of the newly organized American Provisional Executive Committee for General Zionist Affairs that intended to continue the work of the World Zionist Organization in the neutral states. Yet because of his contacts with the British Foreign Office, and especially with ambassador Cecil Spring-Rice, he was considered as an 'informant' during the war. Before and even more so after 1917, Gottheil crossed the lines on several occasions and as a result he and his wife would be shunned later on by others within the American Jewish community. It was, for example, his vetoing dispatch that forced Israel Friedlaender, who intended to become engaged in relief work on behalf of Eastern European and Palestinian Jews, to resign from his appointment to a mission of the Red Cross in Palestine in 1918 (Magnes 1918, pp. 168-69) ${ }^{19}$. With the gradual shift to a pro-Allied sentiment at the American (Jewish) home front since 1915/16 Gottheil's singling out of potential 'disloyal', i.e., pro-German Jews at home could no longer be ignored-regardless of how unfounded these allegations were. His earlier public statements as well as his tart comments to the British press in 1914 claiming, for example, that "intellectual Jewry" in the United States "was largely on the side of the allies" (Gottheil to Kallen, 2 November 1914, ibid.), by contrast, had initially been very much contested. They even became a disputed issue regarding his membership in the (officially neutral) Zionist Organization (on Gottheil's role in American Zionism, see (Cohen 2003, p. 52)).

Zionism as an issue emerged with new intensity beginning in mid-1915, especially in the Anglo American context. The already-mentioned Lucien Wolf in London, for example, proposed a "pro-Allies propaganda among the Jews of the United States". Against the background of ongoing public discourses in Britain, Wolf's suggestions were however more complex (Wolf 1915). Although he was an anti-Zionist, Wolf hoped that calling on Jewish sympathies with regard to Jewish nationalist aspirations in Palestine could turn the tide of pro-British sympathy among Americans. ${ }^{20}$ Furthermore, a comment of the British Ambassador to Washington D.C., Cecil Spring-Rice, who agreed with Wolf's analysis, stressed the danger that the pro-German sentiment ascribed to American Jews could also worsen the situation of Anglo-'Jewry at home (Spring-Rice to Cecil, 29 January 1916, TNA, pp. 315-18). At this time, Wolf was still the preferred broker between Anglo Jewish interests and the British Foreign Office. This would change afterwards with the rise of Chaim Weizmann and the concretization of Zionist aspirations in Palestine, leading finally to the Balfour Declaration in November 1917. Weizmann, who was born in the Russian Empire, educated in Germany, and located in Manchester beginning in 1904, was chosen to head the Zionist Movement in Britain. As James Renton has argued, in this case, the British government clearly overestimated the possible impact of Anglo Jewry on American Jewish affairs, and hence, the intensity of Jewish solidarity in the Anglo American sphere (Renton 2007, pp. 130-33). What is clear, however, is that the First World War shifted Jewish hierarchies. The successes scored by the Zionists in the political field as well as the new gatekeeper role asserted by the JDC, in supervising relief work abroad, lent American Jewry a significant degree of influence in world Jewish affairs. This new-found status was especially challenging to the previous position held by the Jewish elite in Germany.

The controversy about Richard Gottheil as well as Lucien Wolf's efforts to influence public opinion in the US, are cases in point for the complex transnational entanglements of American Jewry: All major parties to the conflict aimed at influencing the public opinion and sympathies of American Jews. Such efforts were carried out in particular by official German or British representatives (i.e., ambassadors)

19 Friedlaender claimed that his knowledge of Arabic could improve the relations between Arabs and Jews in Palestine. Finally, in 1920 Friedlaender participated in a special JDC mission to Eastern Europe. In this context he was murdered, alongside Rabbi Bernard Cantor, on a trip to the Ukraine to distribute relief to Jews (Beizer 2003).

20 Given its different scope, the article cannot address Zionist aims and hopes in and for Palestine and their international entanglements in more detail. For a good overview on the imperial dimension, see (Schnitzer 2007, pp. 148-89). 
in the United States and aided by their Jewish citizens abroad. They, in turn, saw this as an ideal opportunity to express the compatibility of their Jewish and civic loyalties from a distance. ${ }^{21}$

In Germany, it was particularly the Zionists, with their dominant role in the Komitee für den Osten (Committee for the East, CFE), who tried to influence the sentiment of American Jews to their country's advantage. Moderate German Zionists had established the CFE shortly after the outbreak of the war. They claimed that the intentions of Imperial Germany and of Jews in Eastern Europe were identical in terms of their outcome: to bring German culture to Eastern Europe. Therefore, they put emphasis, for instance, on the notion that the Yiddish language spoken by Eastern European Jews was more or less an old German dialect that would be of eminent importance for the German government when it pursued its goal of Germanizing the Polish parts of those multi-ethnic regions in the 'East' that had been under Czarist rule before their occupation by German troops (General Report, January 1915, LBIJMB, p. $6^{22}$ ). Along similar strategic lines, but clearly adapted to the circumstances of the American context, the CFE had sent an envoy from Germany, Isaak Straus, to New York to further its propaganda mission. Straus was instructed to transmit to the Jews in the United States the image of Germany's just struggle against Russia and the alleged positive impact a victory of the Central Powers might have on the situation of the Jews in Eastern Europe (Instructions n.d., LBIJMB).

Moreover, Straus had close contacts to the German ambassador in Washington, Count Johann Heinrich Bernstorff, and the Undersecretary of State at the German Foreign Office, Arthur Zimmermann. Together they aided each other in creating a positive 'German' image addressed to the American Jewish public, stressing the efforts of the German government on behalf of Jews in Eastern Europe. In this context, special attention was given to a letter Bernstorff had written in November 1914 to Herman Bernstein, the editor of the widely read New York Yiddish-language daily newspaper Der Tog (The Day). Bernstorff's goal was to disprove reports published in Russian newspapers that German soldiers had committed atrocities against Jewish civilians during their advance into what was formerly known as Congress Poland. From a Jewish point of view Bernstorff's letter was even more decisive because it publicly declared that a German victory would bring the longed for and overdue emancipation of the Jews in Russia (Committee for the East to Count Bernstorff n.d., ibid.; Count Bernstorff to Bernstein, 10 November 1914, ibid.).

At first glance, it seemed a promising move on the part of Jewish propaganda activists from Germany to target these concerns within the American Jewish community, and especially in New York. Yet the efforts of German Jewish propaganda activists in the United States were not the only source of information available to American Jews. And private correspondence, sometimes even preceding the busy activities of Straus, point to a conflicting counter-image that is often ignored when analyzing only newspaper articles or other official sources (see, e.g., (Herrmann to Levin, 24 September 1914, CZA)). Hence, many of the voiced sentiments of Jewish war enthusiasm in Germany that were part of a larger trend of patriotic propaganda resembled not so much a changed reality, but rather the contemporaries' hopes for the future (Deutschland und die Judenfrage, 29 December 1914, AJA).

For American Jews of Central European descent, like German Americans in general, the way from neutrality via preparedness to active involvement in the war brought a different and more disappointing outcome. And the longer the war in Europe lasted, the more difficult their situation grew: the entry of the United States into the war in April 1917 made being identified as 'German' in the American context an even more difficult challenge. It turned not only those Jews and non-Jews of German birth or citizenship into potential 'enemy aliens', but also pointed to an American concept of citizenship, which now included an exclusive element of nationalism. Hence, the 'enemy from within' was not necessarily defined in political-legal terms having primarily to do with naturalization as such but even more so included foreign heritage and culture as an allegedly dangerous form of separatism

21 On similar attempts by the French Comité de propagande français auprès des juifs neutres, see (Fink 2004, p. 86).

22 For further details on the founding of the Committee for the East, see (Szajkowski 1965, p. 30). 
and disloyalty. This applied alike to Jews and non-Jews, erasing as it were the inherent diversity that 'German' had previously implied. For similar to the situation at the outbreak of the war in Britain, public perception linked a clearly negatively connoted 'Germanness' with fears of spy activities for the nation's enemy and thus with disloyalty and treason (Nagler $2000^{23}$ ). Furthermore, paralleling more general trends within American society, until April 1917 many American Jews had moved in a pro-Allied direction. Hence, paralleling the patriotic mobilization of Jews in other nations at the outbreak of the war in the summer of 1914, many native-born (as well as foreign-born) Jewish citizens now flocked to the arms.

\section{Conclusions}

Although the American nation was not involved directly in the war in the summer of 1914, the situations in Europe and the Middle East clearly influenced the debate of American Jews about their multiple loyalties and notions of cultural belonging in the midst of American neutrality. Like other social, religious, political or ethnic groups with transnational bonds, American Jews were thus deeply affected by this ever more globalizing war. Specific to the Jewish situation, when comparing it with those of other groups or sectors within American society, such as Irish Americans, Polish Americans, Italian Americans or African Americans, was that their multiple loyalties at many occasions turned them into transatlantic 'enemies from within'. In this context, their emotional state of mind, and sometimes even the personal affiliations themselves, overlapped partly with the situation of German Americans, who faced the most violent attacks and suspicions of disloyalty on the American home front during the war. Many American Jews, who tried to prove their unquestioned loyalty as citizens, interpreted the course of American neutrality matching notions of a distinctively Jewish love of peace. Putting forth this image, at first, enabled American Jews to propagate the compatibility of notions of Jewish solidarity and considerations of civic loyalty toward the American nation.

Until April 1917, American Jews, amidst the huge toll the war took on Jewish civilians' lives in Eastern Europe and the Middle East, distanced themselves therefore from a war they associated with two fears: First, an unprecedented Jewish fratricide on the battlefields of Europe, involving their families, co-religionists and business partners and, second, a symbolic re-enactment of belligerent front lines in the American (Jewish) public sphere. Paralleling what Randolph Bourne in 1916 called "Trans-National America", i.e., "a weaving back and forth, with other lands, of many threads of all sizes and colors", (Bourne [1916] 1996, p. 106) the war deepened pre-war cleavages within the American context, such as the one between native ('American') Jews and foreign ('Russian') Jews. Even more significantly, one effect of the war itself was that the 'nativeness' of American Jews was questioned (Friedlaender [1915] 1919, p. 341). Correspondingly, the foreseeable continuation of the war at the end of 1914 clearly had a major impact on the question of how to balance divergent sympathies within American Jewry, making it increasingly difficult for American Jews to remain neutral. As a result, the relationship between notions of a (transnational) Jewish solidarity and bonds of civic loyalty was challenged as well. Central for this development was, among other things, the perception 'at home' and 'abroad' that Jews in the United States-regardless of their actual citizenship status or cultural self-identifications-were pro-German and/or anti-Russian.

As this article has attempted to demonstrate, an analysis of American Jews as 'neutral' actors with a transatlantic heritage has the potential to open up a multi-sided perspective on Jewish attitudes at the outbreak of the First World War. In so doing, it challenges us to answer the question of what was specific to one national context and what was part of a more general trend-a critical corrective that is often lacking when focusing only on the war's impact on American Jews 'at home'. Finally, such an approach makes also visible that Jews in non-belligerent countries were not only far from being

23 The number and the share of the population of Germans in the US was, however, much larger than in Britain. (Ellis and Panayi 1994, pp. 252-53). 
'neutral' spectators from the distance, but also highly entangled with, involved in and influenced by the situation of Jewish communities beyond their own borders. As in the case of other ethnic minorities, there was no unified Jewish answer or response to the outbreak of the war. In this sense, too, this article connects to larger debates within American history about the nation's "'forgotten war'" (Keene 2014).

Conflicts of Interest: The author declares no conflict of interest.

\section{References and Notes}

Archival Sources

Cecil Spring-Rice to Robert Cecil, 29 January 1916. FO 115/2074. Kew: The National Archives, Public Record Office (TNA).

Committee for the East to Count Bernstorff n.d. MF 13-2. Berlin: Committee for the East, Leo Baeck Institute Archives, Holdings at the Jewish Museum (LBIJMB).

Count Bernstorff to Herman Bernstein, 10 November 1914. MF 13-2. Berlin: Committee for the East, Leo Baeck Institute Archives, Holdings at the Jewish Museum (LBIJMB).

Deutschland und die Judenfrage, 29 December 1914. Box 165, Folder 3, MS-457. Cincinnati: American Jewish Archives (AJA).

General Report for the Members of the Committee for the East, January 1915. MF 13-1. Berlin: Committee for the East, Leo Baeck Institute Archives, Holdings at the Jewish Museum (LBIJMB), p. 6.

Instructions for Journey to America n.d. MF 13-2. Berlin: Committee for the East, Leo Baeck Institute Archives, Holdings at the Jewish Museum (LBIJMB).

Jacob Schiff to Lucien Wolf, 14 June 1915. Folder 32, A77. Jerusalem: Central Zionist Archives (CZA).

Jacob Schiff to Paul Nathan and Max Warburg, 16 February 1915. Box 444, Folder 16, MS-456. Cincinnati: American Jewish Archives (AJA).

Leo Herrmann to Schmarja Levin, 24 September 1914. Folder 395, Z3. Jerusalem: Central Zionist Archives (CZA).

Louis Marshall to Jacob Schiff, 30 December 1914. Box 439, Folder 1, MS-456. Cincinnati: American Jewish Archives (AJA).

Louis Marshall to Jacob Schiff, 30 October 1914. Box 439, Folder 1, MS-456. Cincinnati: American Jewish Archives (AJA).

Lucien Wolf. Suggestions for a Pro-Allies Propaganda among the Jewish of the United States, 16 December 1915. RG-348, Folder 72. New York: Center for Jewish History, YIVO Archives.

Richard Gottheil to Horace Kallen, 19 October 1914. Box 12, Folder 1, MS-1. Cincinnati: American Jewish Archives (AJA).

Richard Gottheil to Horace Kallen, 2 November 1914. Box 12, Folder 1, MS-1. Cincinnati: American Jewish Archives (AJA).

Stephen S. Wise to Richard Gottheil, 2 February 1917. Box 2, Folder 3, MS-127. Cincinnati: American Jewish Archives (AJA).

Published Sources

Abramson, Glenda. 2008. Hebrew Writing of the First World War. London: Vallentine Mitchell \& Co Ltd.

American Hebrew. 1914a. The Military Spirit. American Hebrew, August 14, p. 413.

American Hebrew. 1914b. The Teuton against the Slav. American Hebrew, August 14, p. 411.

American Hebrew. 1914c. Jews in England Charged with German Sympathies. American Hebrew, August 21, p. 430.

American Hebrew. 1915. Russian Atrocities in Poland. American Hebrew, February 5, p. 371.

American Israelite. 1914. Jews Mistaken for Germans. American Israelite, August 27, p. 3.

American Israelite. 1914. True Patriotism. American Israelite, October 10, p. 1.

American Jewish Year Book. 1918-1919. Statistics of Jews. A. Jewish Population of the World. American Jewish Year Book 20: 340. Available online: http:/ / www.ajcarchives.org/main.php?GroupingId=10051 (accessed on 5 June 2018). 
American Jewish Year Book. 1916-1917. Ninth Annual Report of the American Jewish Committee, 14 November 1915. American Jewish Year Book 18: 307-10. Available online: http://www.ajcarchives.org/main.php? GroupingId=10049 (accessed on 6 April 2018).

American Jewish Year Book. 1917-1918a. Jewish War Relief Work. American Jewish Year Book 19: 194-227. Available online: http:/ / www.ajcarchives.org/main.php?GroupingId=10050 (accessed on 6 April 2018).

American Jewish Year Book. 1917-1918b. Statistics of Jews: A. Jewish Population of the World. American Jewish Year Book 19: 409-10. Available online: http:/ / www.ajcarchives.org/main.php?GroupingId=10050 (accessed on 6 April 2018).

Ansky, S. 2002. The Enemy at His Pleasure: A Journey through the Jewish Pale of Settlement during World War I. Edited and Translated by Joachim Neugroschel. New York: Metropolitan Books. First published in 1925.

Aschheim, Steven E. 1982. Brothers and Strangers: The East European Jew in German and German Jewish Consciousness, 1800-1923. Madison: University of Wisconsin Press.

Beizer, Michael. 2003. Who Murdered Professor Israel Friedlaender and Rabbi Bernard Cantor: The Truth Rediscovered. American Jewish Archives Journal 55: 63-114.

Bourne, Randolph S. 1996. Trans-National America. In Theories of Ethnicity: A Classical Reader. Edited by Werner Sollors. Basingstoke: Macmillan, pp. 93-109. First published in 1916.

Brinkmann, Tobias. 2014. "German Jews?" Reassessing the History of Nineteenth-Century Jewish Immigrants in the United States. In Transnational Traditions: New Perspectives on American Jewry. Edited by Ava F. Kahn and Adam D. Mendelsohn. Detroit: Wayne State University Press, pp. 144-64.

Capozzola, Christopher. 2008. Uncle Sam Wants You. World War I and the Making of the Modern American Citizen. New York: Oxford University Press.

Carenen, Caitlin. 2017. Zionism and American Jewish Relief Efforts in Palestine during World War I. American Jewish Archives Journal 69: 1-29.

Carenen, Caitlin. 2017. Complicating the Zionist Narrative in America: Jacob Schiff and the Struggle over Relief Aid in World War I. American Jewish History 101: 441-63. [CrossRef]

Cohen, Naomi Wiener. 2003. The Americanization of Zionism, 1897-1948. Hanover: Brandeis University Press.

Daniel, Silvia. 2008. A Brief Time to Discuss America: Der Ausbruch des Ersten Weltkriegs im Urteil amerikanischer Politiker und Intellektueller, Göttingen: V\&R Unipress.

Diner, Hasia R. 2004. The Jews of the United States: 1654 to 2000. Berkeley: University of California Press.

Dobbert, G. A. 1968. The Ordeal of Gotthard Deutsch. American Jewish Archives Journal 20: 129-55.

Ellis, Mark, and Panikos Panayi. 1994. German Minorities in World War I: A Comparative Study of Britain and the USA. Ethnic and Racial Studies 17: 238-59. [CrossRef]

Engelman, Morris. 2016. Four Years of Relief and War Work by the Jews of America, 1914-1918: A Chronological Review. New York: Wentworth Press. First published in 1918.

Estraikh, Gennady. 2017. American Yiddish Socialists at the Wartime Crossroads: Patriotism and Nationalism versus Proletarian Internationalism. In World War I and the Jews: Conflict and Transformation in Europe, the Middle East, and America. Edited by Marsha L. Rozenblit and Jonathan Karp. New York: Berghahn Books, pp. 279-302.

Ewence, Hannah, and Tim Grady, eds. 2017. Minorities and the First World War: From War to Peace. Basingstoke: Palgrave Macmillan.

Fink, Carole. 2004. Defending the Rights of Others: The Great Powers, the Jews, and International Minority Protection, 1878-1938. New York: Cambridge University Press.

French, John. 2012. Irish-American Identity, Memory, and Americanism during the Eras of the Civil War and First World War. Ph.D. dissertation, Marquette University, Milwaukee, WI, USA. Available online: https: / / epublications.marquette.edu/cgi/viewcontent.cgi?article=1194\&context=dissertations_mu (accessed on 28 May 2018).

Friedlaender, Israel. 1919. The Present Crisis in American Jewry: A Plea for Reconciliation. In Past and Present: Collected Essays. Edited by Israel Friedlaender. New York: Ark, pp. 331-52. First published in 1915.

Frommer, Morris. 1978. The American Jewish Congress: A History, 1914-1950, Volume I. Ph.D. dissertation, Ohio State University, Columbus, OH, USA. Available online: https:/ / etd.ohiolink.edu/ (accessed on 6 April 2018).

Gerstle, Gary. 2001. American Crucible: Race and Nation in the Twentieth Century. Princeton: Princeton University Press.

Gidley, Ben Peter. 2003. Citizenship and Belonging: East London Jewish Radicals, 1903-1918. Ph.D. dissertation, University of London, London, UK. 
Goren, Arthur A. 1999. Paths of Leadership: In the Politics and Public Culture of American Jews. Edited by Arthur Goren. Bloomington: Indiana University Press, pp. 110-44.

Granick, Jaclyn. 2014. Waging Relief: The Politics and Logistics of American Jewish War Relief in Europe and the Near East, 1914-1918. First World War Studies 5: 55-68. [CrossRef]

Greiner, Bernd. 1995. Unerwünschter Protest. Henry Morgenthau sen. als Botschafter in der Türkei. Mittelweg 36: 24-28.

Handlin, Oscar. 1964. A Continuing Task: The American Jewish Joint Distribution Committee, 1914-1964. New York: Random House.

Higham, John. 2007. Strangers in the Land: Patterns of American Nativism, 1860-1925. New York: Rutgers University Press. First published in 1955.

Hilfsverein der deutschen Juden. 1917. Fünfzehnter Geschäftsbericht (für das Jahr 1916). Berlin: Selbstverlag.

Houlihan, Patrick J. 2015. Catholicism and the Great War: Religion and Everyday Life in Germany and Austria-Hungary, 1914-1922. Cambridge: Cambridge University Press.

Ingrao, Charles W., and Franz A. J. Szabo, eds. 2007. The Germans and the East. West Lafayette: Purdue University Press. Jewish Comment. 1914. Editorials. Jewish Comment, August 28, 258.

Jewish Criterion. 1914a. Neutrality. Jewish Criterion, October 23, 3.

Jewish Criterion. 1914b. The War. Jewish Criterion, October 30, 8.

Jewish Criterion. 1915. Charity Begins at Home. Jewish Criterion, June 11, 5.

Jüdische Rundschau. 1915. Das Leiden der Juden in Polen: Zweiter offener Brief an "The American Hebrew". Jüdische Rundschau, February 5, 45-6.

Kahn, Ava F., and Adam D. Mendelsohn, eds. 2014. Transnational Traditions: New Perspectives on American Jewry. Detroit: Wayne State University Press.

Kallen, Horace M. 1996. Democracy versus the Melting-Pot: A Study of American Nationality. In Theories of Ethnicity: A Classical Reader. Edited by Werner Sollors. Basingstoke: Macmillan, pp. 67-92. First published in 1915.

Keene, Jennifer D. 2014. Americans Respond: Perspectives on the Global War, 1914-1917. Geschichte und Gesellschaft 40: 266-86. [CrossRef]

Keene, Jennifer D. 2016. Remembering the "Forgotten War": American Historiography on World War I. The Historian 78: 439-68. [CrossRef]

Kennedy, David M. 1980. Over Here: The First World War and American Society. New York: Oxford University Press.

Kennedy, David M. 1993. American Political Culture in a Time of Crisis: Mobilization in World War I. In Confrontation and Cooperation: Germany and the United States in the Era of World War I, 1900-1924. Edited by Hans-Jürgen Schröder. Providence: Berg, pp. 213-27.

Kotzin, Daniel P. 2010. Judah L. Magnes. An American Jewish Nonconformist. Syracuse: Syracuse University Press.

Lambroza, Shlomo, and John Klier, eds. 1992. Pogroms: Anti-Jewish Violence in Modern Russian History. Cambridge: Cambridge University Press.

Lederhendler, Eli. 1997. Jewish Responses to Modernity: New Voices in America and Eastern Europe. New York: New York University Press.

Lederhendler, Eli. 2016. American Jewry: A New History? Cambridge: Cambridge University Press.

Leonhard, Jörn. 2018. Pandora's Box: A History of the First World War. Cambridge: Belknap Press.

Levene, Mark. 1992. War, Jews, and the New Europe: The Diplomacy of Lucien Wolf, 1914-1919. Oxford: Oxford University Press.

Liulevicius, Vejas Gabriel. 2000. War Land on the Eastern Front: Culture, National Identity, and German Occupation in World War I. Cambridge: Cambridge University Press.

Loeffler, James. 2015. Nationalism without a Nation? On the Invisibility of American Jewish Politics. Jewish Quarterly Review 105: 367-98. [CrossRef]

Lohr, Eric. 2003. Nationalizing the Russian Empire: The Campaign against Enemy Aliens during World War I. Cambridge: Harvard University Press.

Luebke, Frederick C. 1974. Bonds of Loyalty: German-Americans and World War I. DeKalb: Northern Illinois University Press. Magnes, Judah L. 1918. Statement to Members of the Joint Distribution Committee, 11 March 1918. In Dissenter in Zion. From the Writings of Judah L. Magnes. Edited by Arthur A. Goren. Cambridge: Harvard University Press 1982, pp. 368-69.

Magnes, Judah L., ed. 1923. War-Time Addresses, 1917-1921. New York: Thomas Seltzer.

Manela, Erez. 2009. The Wilsonian Moment: Self-Determination and the International Origins of Anticolonial Nationalism. New York: Oxford University Press. 
Manor, Ehud. 2009. Forward. The Jewish Daily Forward (Forverts) Newspaper. Immigrants, Socialism, and Jewish Politics in New York, 1890-1917. Brighton: Sussex Academic Press.

Marcus, Jacob Rader, and Judith M. Daniels, eds. 1994. The Concise Dictionary of American Jewish Biography. Brooklyn: Carlson Pub.

Morgenthau, Henry. 1919. Ambassador Morgenthau's Story. New York: Doubleday, Page \& Company.

Nagler, Jörg. 2000. Nationale Minoritäten im Krieg: 'Feindliche Ausländer' und die Amerikanische Heimatfront während des Ersten Weltkriegs. Hamburg: Hamburger Edition.

Nickles, David Paull. 2003. Under the Wire: How the Telegraph Changed Diplomacy. Cambridge: Harvard University Press.

Oren, Michael B. 2007. Power, Faith, and Fantasy: America in the Middle East, 1776 to Present. New York: W. W. Norton \& Company.

Panter, Sarah. 2014. Jüdische Erfahrungen und Loyalitätskonflikte im Ersten Weltkrieg. Göttingen: Vandenhoeck \& Ruprecht. Penslar, Derek J. 2013. Jews and the Military: A History. Princeton: Princeton University Press.

Proctor, Tammy M. 2014. "Patriotic Enemies": Germans in the Americas, 1914-1920. In Germans as Minorities during the First World War: A Global Comparative Perspective. Edited by Panikos Panayi. Farnham: Ashgate, pp. 213-34.

Rappaport, Joseph. 2005. Hands across the Sea: Jewish Immigrants and World War I. Lanham: Hamilton Books. First published in 1951.

Renton, James. 2007. The Zionist Masquerade: The Birth of the Anglo-Zionist Alliance, 1914-1918. Basingstoke: Palgrave Macmillan.

Safran, Gabriella. 2010. Rapoport, Shloyme Zaynvl. In YIVO Encyclopedia of Jews in Eastern Europe. Available online: http:/ / www.yivoencyclopedia.org/article.aspx/Rapoport_Shloyme_Zaynvl (accessed on 6 April 2018).

Sanders, Michael, and Philip M. Taylor. 1982. British Propaganda during the First World War, 1914-1918. London: Macmillan.

Saperstein, Marc. 2010. Western Jewish Perceptions of Russian Jews at the Beginning of the First World War. European Judaism 43: 112-27. [CrossRef]

Schnitzer, Shira. 2007. Imperial Longings and Promised Lands: Anglo-Jewry, Palestine and the Empire, 1899-1948. Ph.D. dissertation, University Oxford, Oxford, UK.

Silver, M. M. 2017. Louis Marshall during World War I: Change and Continuity in Jewish Culture and Politics. In World War I and the Jews: Conflict and Transformation in Europe, the Middle East, and America. Edited by Marsha L. Rozenblit and Jonathan Karp. New York: Berghahn Books, pp. 303-25.

Sterba, Christopher. 2003. Good Americans: Italian and Jewish Immigrants during the First World War. New York: Oxford University Press.

Stibbe, Matthew. 2014. Enemy Aliens, Deportees, Refugees: Internment Practices in the Habsburg Empire, 1914-1918. Journal of Modern European History 12: 479-99. [CrossRef]

Szajkowski, Zosa. 1965. Jewish Relief in Eastern Europe, 1914-1917. The Leo Baeck Institute Year Book 10: 24-56. [CrossRef]

Szajkowski, Zosa. 1972. The Attitude of American Jews to World War I, the Russian Revolutions of 1917, and Communism (1914-1945). New York: KTAV Publishing House.

Tessaris, Chiara. 2010. The War Relief Work of the American Jewish Joint Distribution Committee in Poland and Lithuania, 1915-1918. East European Jewish Affairs 40: 127-44. [CrossRef]

Times (London). 1914. Jew and German: A Protest against Unfair Suspicion. Times, (London). August 15, p. 3.

Tooze, Adam. 2014. The Deluge: The Great War, America and the Remaking of the Global Order, 1916-1931. New York: Viking Penguin.

Traxel, David. 2006. Crusader Nation: The United States in Peace and the Great War, 1898-1920. New York: Knopf.

Wilson, Woodrow. 1914. Message on Neutrality, 19 August 1914. In The American Presidency Project. Edited by Gerhard Peters and John T. Woolley. Available online: http:/ / www.presidency.ucsb.edu/ws / ?pid=65382 (accessed on 6 April 2018).

Wüstenbecker, Katja. 2014. German-Americans during World War I. In Immigrant Entrepreneurship: German-American Business Biographies, 1720 to the Present. Washington: German Historical Institute. Available online: http:/ / www.immigrantentrepreneurship.org/entry.php?rec=214 (accessed on 28 May 2018).

Zahra, Tara. 2016. The Great Departure: Mass Migration from Eastern Europe and the Making of the Free World. New York: W. W. Norton \& Company.

(C) 2018 by the author. Licensee MDPI, Basel, Switzerland. This article is an open access article distributed under the terms and conditions of the Creative Commons Attribution (CC BY) license (http:/ / creativecommons.org/licenses/by/4.0/). 